\title{
Mapping the potential for tourism strategic areas to improve the equality of development in Bali
}

\author{
Nyoman M. Jaya ${ }^{1 *}$, Ngakan M. Anom Wiryasa ${ }^{1}$, Dewa Ketut Sudarsana ${ }^{1}$, and Putu D.P. \\ Salain ${ }^{2}$ \\ ${ }^{1}$ Department of Civil Engineering, Universitas Udayana, Denpasar, Indonesia \\ ${ }^{2}$ Department of Civil Engineering, Bali State Polytechnic, Bali, Indonesia
}

\begin{abstract}
Government Regulation of the Republic of Indonesia (PPRI number 50/2011) indicates the declaration of the National Tourism Development Master Plan (RIPParNas) from 2010 to 2025. Eighty-eight (88) of the National Tourism Strategic Areas $(K S P N)$ is spread on thirty four (34) provinces throughout the territory of the Republic of Indonesia. The province of Bali contributes greatest foreign exchange for Indonesia through the tourism sector. Eleventh $\left(11^{\text {th }}\right)$ of KSPN-Bali are reflecting a priority-program of Indonesian Government through equal development of Tourism Strategic Areas. Development for Bali still indicates gap between a remote regency and central city. The moratorium on rapid development of tourism facility in South Bali indicates quite difference with slower development of East and North Bali. Thus, efforts to increase the distribution of development require investigation and identification through mapping the potential of Natural Resources and Cultivation, especially, the area of tourism in South Bali (Denpasar/Badung) compared to East (Karangasem) and North (Buleleng). Literature review, field observation, and semi-structured interview data were analysed by combination of qualitative-verification methods and cognitive-mapping solutions. The result of case study was representing mapping the potentials for natural resources and cultivation that was identified in Sanur (Denpasar), Tulamben-Amed (Karangasem), and Bali-Utara (Buleleng). Therefore, unequal development between each tourism strategic areas would reduce, and in turn, prosperity of social communities would be improving for Bali.
\end{abstract}

\section{Introduction}

President of the Republic of Indonesia proclaims the Master Plan of National Tourism Development (RIPParNas: 2010-2025) on December 2, 2011. Government Regulation number 50 the Year 2011 on RIPParNas [1], has established four main pillars of tourism development in Indonesia, covering: 1) tourism destinations, 2) the tourism industry, 3) tourism marketing, and 4) tourism institutions.

\footnotetext{
*Corresponding author: nmjaya@unud.ac.id
} 
Bali as the largest foreign exchange contributor of the tourism sector has eleven (11) National Tourism Strategic Areas (KSPN) among eighty-eight (88) KSPN spread across thirty-four (34) provinces throughout the territory of the Republic of Indonesia. KSPN Bali is located in all regencies and cities (PPRI'50, 2011) [1], namely: Buleleng Regency: North Bali Area (Singaraja) and surrounding areas, Buleleng Regency: Menjangan Island AreaPemuteran and surrounding areas, Jembrana District: Bali Barat National Park Area, Regency of Tabanan: Bedugul and surrounding areas, Denpasar City and Badung District: Sanur-Kuta-Nusa Dua and surrounding areas, Kelungkung regency: Nusa Penida and surrounding areas, Gianyar regency: Ubud and surrounding areas, Bangli regency: Kintamani area-Lake Batur and surrounding areas, Karangasem regency: Besakih-Gunung Agung and surrounding areas, Tulamben-Amed and surrounding areas, Labuhan Amuk area and surrounding areas. The appointment of the eleventh KSPN Bali, reflecting the Government of the Republic of Indonesia's goal of 'Development of Bali Tourism Strategic Area in Equalization of Development.'

The development of Bali in general, there are still gaps in the results of development between the Regency and City, especially East and North Bali. Thus, the establishment of KSPN (2010-2025) indicates the priority of strategic tourism area development focused in Karangasem Regency in three strategic areas, while in Buleleng Regency, two strategic regions are developed; and each there is only one strategic area development in other regencies/cities in Bali.

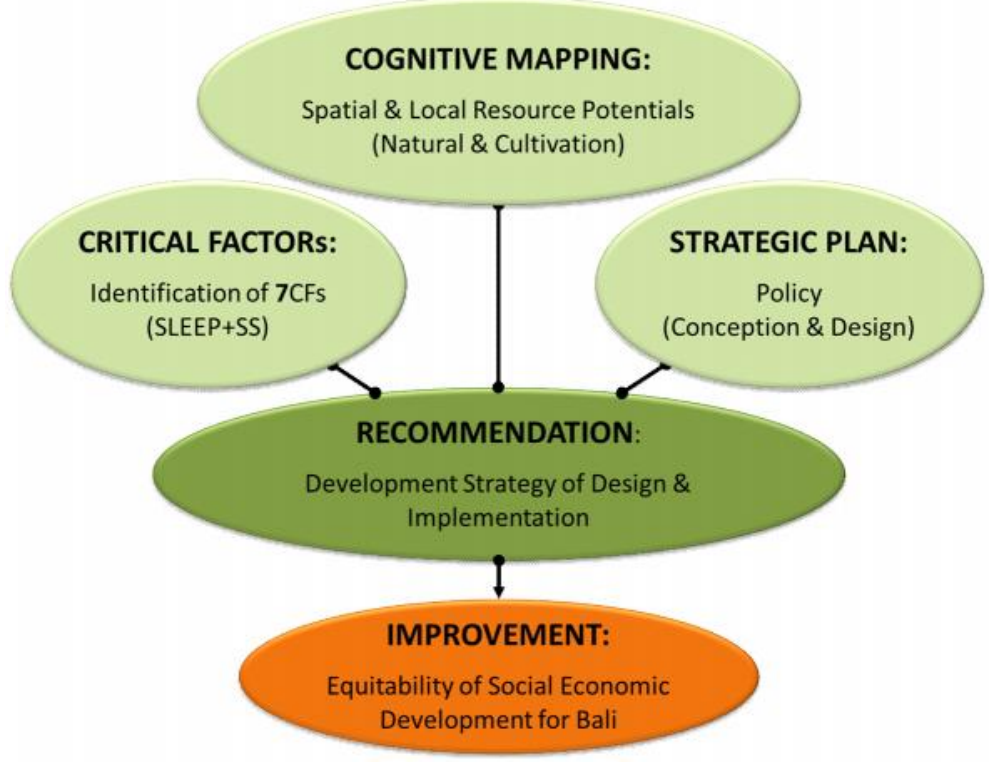

Fig. 1. Conceptual framework of research plan.

Development-strategic for Bali can be supported by various philosophies that are quite relevant, namely: independence uniqueness (Mandiri), excellence competitiveness (Unggul), cultural (Berbudaya). Therefore, it would be investigated and developed three important independent-themes [2]: Critical Factors (CFs); Cognitive Mapping the spatial knowledge and local resource potentials; and Strategic development plan. Mainly in this research focused on scientific mapping the local potentials in the form of natural and cultivation resources. Mapping the potentials of strategic tourism areas is an information database as a reference document which is beneficial preparations for development strategy of sustainable tourism areas to increase equitability of social and economic development for Bali Province. The series of studies can be described briefly in Fig. 1. 


\section{Literature review}

The integrated literature review is beneficial to observe and synthesize the results of recent research to make inference judgment and organize ideas related to a particular field of study [3]. The synthesis process is crucial when it comes to identifying and understanding 'research problems' that require appropriate solutions to achieve 'research objectives' through a systematic scientific method. The literature review phase is intended to identify and analyse influential variables [2], such as Social-culture, Legal-regulation, Environment, Economic, Politic, Safety, and Sustainability (SLEEP + SS) and "Mapping of the potential of natural and cultivation resources in the National Tourism Strategic Area (KSPN) in supporting equity of development for Bali".

Indonesia as a developing country, then the government expects all components of the nation to continue to develop science and technology, to improve the economy to compete and excel from neighboring countries (Asia), even other countries in the world. President of the Republic of Indonesia issued Presidential Decree No. 32 of 2011 on May 20, 2011, on the Master Plan for the Acceleration and Expansion of Indonesian Economic Development (MP3EI: 2010-2025). Indonesia's economic development is based on the approach of the spatial concept of regional development. The Indonesian economy is developed based on the potential and environmental advantages of each of the thirty-four (34) provinces grouped into six National Economic Corridors (Fig. 2).

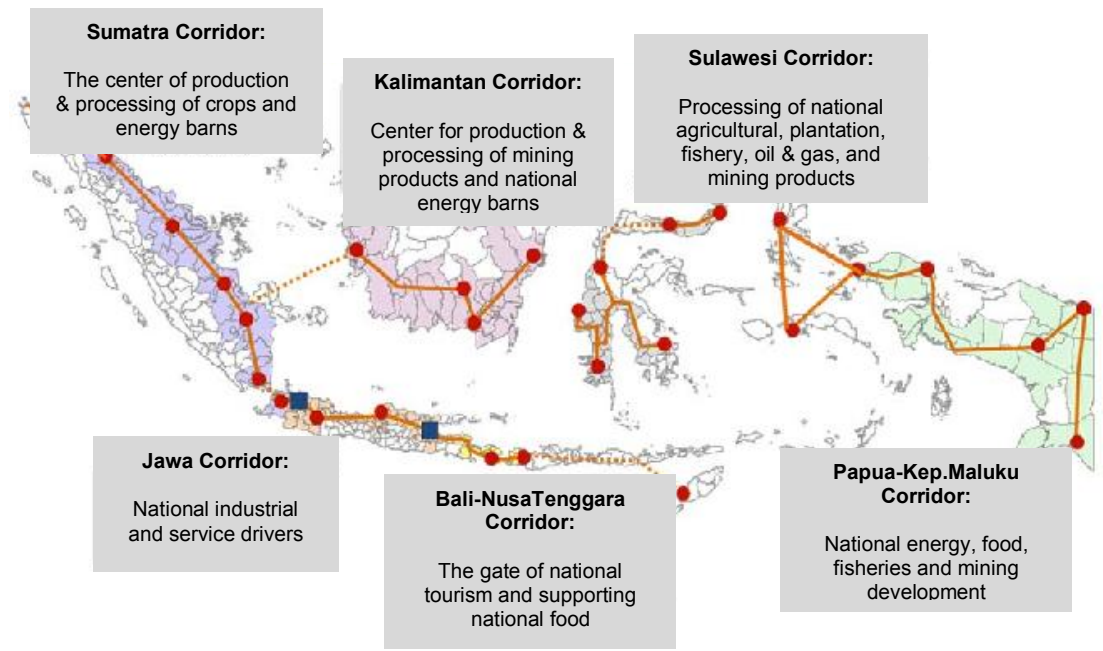

Fig. 2. Development of 6 Indonesian economic corridors [4].

Fig. 2 illustrates six significant areas of acceleration of Indonesia's economic development, consisting of economic corridors of Sumatra, Java, Kalimantan, Sulawesi, Bali-Nusa Tenggara and Papua-Maluku. The MP3EI program is tailored to the characteristics of each of the six economic corridors of Indonesia and is focused on eight main activities: Agriculture, Mining, Energy, Industry, Marine, Tourism, Telematics, and Strategic Area Development. Fig. 3 shows two hundred twenty two (222) 'National Tourism Development Zone (KPPN)', eighty eight (88) 'National Tourism Strategic Area (KSPN)', and all fifty (50) National Tourism Destinations (DPN) including the Bali-Nusa Lembongan DPN.

The 'spatial' concept approach to Indonesia's economic development can be implemented more operational through comprehensive and integrated regional planning of Indonesia (refer to Fig. 3). Furthermore, on December 2, 2011, the President of the 
Republic of Indonesia adopted the National Tourism Development Master Plan (RIPParNas: 2010-2025), through PPRI number 50 of 2011.

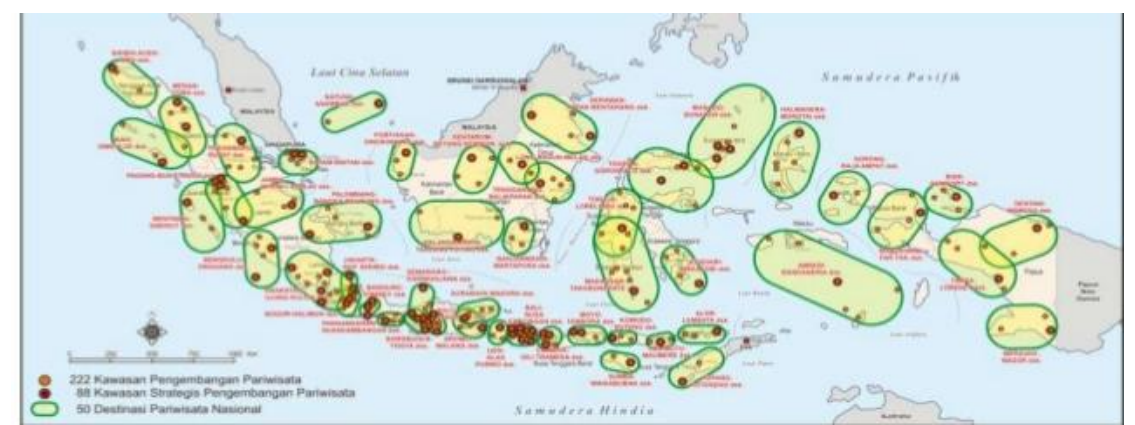

Fig. 3. National tourism destination (50-DPN) $[1,5]$.

The eighty-eight (88) KSPNs in 50 DPNs spread in thirty-four (34) provinces territory of the Republic of Indonesia (Fig. 3). While Bali has eleven (11) KSPNs provide as the most significant foreign exchange contributors to Indonesia from the tourism sector, the 11 KSPNs are scattered throughout the Regency and City in Bali Province [1] - PPRI-50: 2011, are presented in Fig. 3, namely: North Bali Area (Singaraja) and surrounding areas (Buleleng Regency), Menjangan Island Area - Pemuteran and surrounding areas Buleleng), West Bali National Park Area (Jembrana District), Bedugul and surrounding Area (Tabanan District), Sanur Area (Denpasar City), Kuta - Nusa Dua and surrounding areas (Badung Regency), Nusa Penida Region and (Area of Ubud and surrounding area of Gianyar), Kintamani area - Batur Lake and surrounding area (Bangli district), Besakih area-Mount Agung and surrounding area (Karangasem district), Tulamben area-Amed and surrounding areas Karangasem regency), Labuhan Amuk and surrounding areas (Karangasem regency).

The eleventh of KSPN Bali (Fig. 4) illustrates the medium-term objective of the Government of the Republic of Indonesia for 'Development of Strategic Tourism Area of Bali Province in Supporting Equity of Development.' Based on the identification of the development map of Bali tourism area generally indicates there is still a gap of development results between regencies and cities so far. For example, the construction of a focused tourism facility in Sanur (Denpasar City) and Kuta-Nusa Dua (Badung Regency) underwent a 'moratorium' policy because the construction of tourism facilities is approaching saturation level. Thus, the establishment of KSPN (2010-2025) proclaims the priority of developing three strategic areas of Bali province focused on Karangasem Regency; meanwhile, two (2) strategic areas are located in Buleleng Regency; and each has only one strategic area development in other regencies in Bali (Jembrana, Tabanan, Bangli, Gianyar, Kelungkung).

Government Regulation of the Republic of Indonesia (PPRI number 50/2011) or RIPParNas 2010-2025 documented a definition of KSPN as a region that has the main function of tourism or has the potential for tourism development which has one or more aspects, such as economic, social \& cultural growth, empowerment of natural resources, environmental carrying capacity, defense and security [1], while the strategic area is defined following Bali Provincial Regulation No. 16/2009; is "the area where spatial planning is prioritized because it has a significant influence in the province's scope on economy, social, culture, tourism and/or environment." Bali Tourism Strategic Area is contained in Regional Spatial Plan (RTRW) for the period of 2009 to 2029 [6-8]. Based on PPRI number 50 in 2011, Bali Province is included in the fifth (V) economic corridor, ie., Bali \& Nusa Tenggara, and MP3EI indicates that contribution the country's foreign 
exchange from the tourism sector can significantly contribute to the equalization of the economic development [9-13] of the so-called societies in the province of Bali, and to be achieved more realistically through the priority of the Tourism Strategic Area Development of Bali Province.

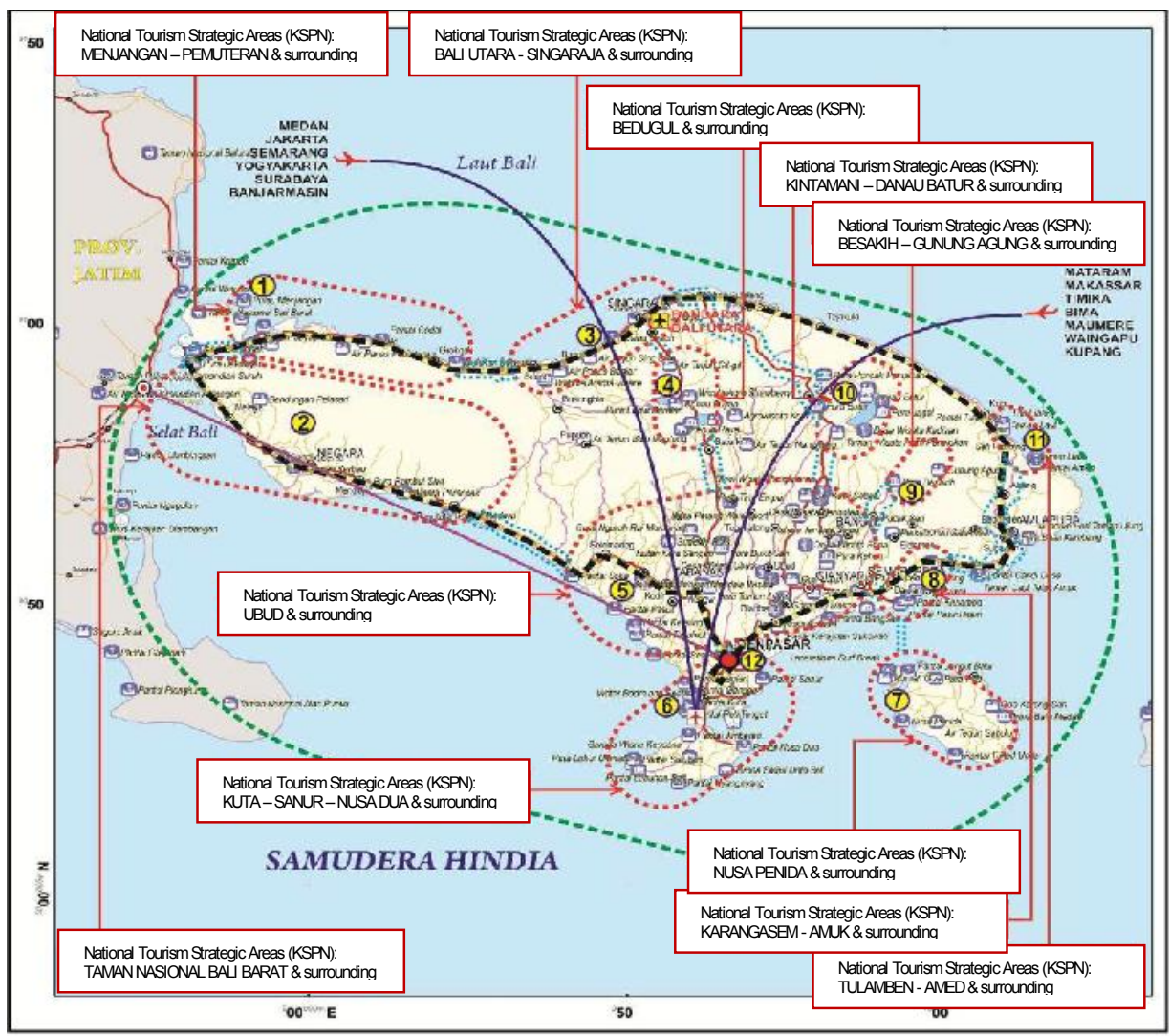

Fig. 4. National tourism strategic area (KSPN) of Bali Province [1].

Jaya and Wiryasa [14] reported the results of the Critical Factors (CFs) investigation into the development of KSPN Bali Province. A careful study of literature and observation identifies fifty-seven (57) essential factors affecting the development of the Tourism Strategic Area (KSP) of Bali Province. All essential factors are grouped into seven (7) CFs categories based on the literature study, field observation and interview/discussion with some relevant experts. Each category of factors is grouped based on the similarity of information contained in each factor, and the proximity of the meaning and meaning of the data. The seven categories of CFs are [2]: Social-cultural, Legal-regulatory, Economic, Environment, Politic, Safety, and Sustainability (SLEEP + SS).

\section{Research methodology}

Literature review, field observation, discussion and interviews with resource persons initiated three main types of research design, as follows: exploratory, constructive, and empirical [15-17]. Exploratory research was designed to know and understand the research situation well and has not produced a final decision or conclusion of the answer. The purpose of the exploratory study is to collect initial information that can help define the 
problem and create a hypothesis. The process of collecting data is secondary such as literature review, or primary approach to qualitative data such as informal discussions (with former officials, community leaders, private entrepreneurs, corporate managers, marketing mediators), and somewhat formal through consultations and interviews with officials as pilot studies. Constructive research is used because the research design is about engineering science. Research is intended to include basic theories, simple mathematical formulas, models or frameworks. Constructive research approaches include validation, but not necessarily exploratory-based as the previous research stage, or for empirical research as used and discussed below.

Empirical research is based on observations to measure the presence of natural phenomena. Knowledge can also be gained from real experience in the field (grounded) rather than from previous theories or beliefs. The empirical research approach is made to obtain the development of science/ knowledge and technology through experience and direct or indirect observation, which then analyzed by quantitative and/or qualitative method [18]. Quantitative data are analyzed triangulated with qualitative data to describe the results of quantitative analysis into qualitative form to be more clearly understood or more reasonable. Empirical researches are used to combine two research traditions, namely quantitative and qualitative methods during data collection and analysis, to solve problems and achieve better research objectives.

This study accommodates all three types of research designs but focuses more on empirical approaches because the research instruments are designed with a quantitative and qualitative design of semi and structured interviews [19]. The semi-structured interviews design constructs a 'qualitative-verification' format in which the 'triangulation strategy' in obtaining data in the field remains open regarding treating theory. One of the advantages of qualitative-verification research is to attempt to reveal the facts behind the apparent data so that these unseen things are subjected to qualitative methods [2].

Respondents' answers are recorded and labeled into each question variable to analyze and measure the level of confidence (information) obtained, and then explained qualitatively to improve the validity of research instruments and data reliability by a combination (triangulation) method $[17,20]$. Thus, the process and research results can be useful for mapping the scientific potential of the tourism region includes the development of strategic areas of national tourism to improve equality of economic development in Bali Province.

\section{Results and discussion}

\subsection{General}

The people of Indonesia need efforts to enhance the quality of life in the activities of nation and state. It is hoped that by improving the quality of life can create wider prosperity as well as providing happiness both in the spirit and in the heart. One of the efforts to improve the quality of life of the community is through tourism activities. Tourism has a central role in creating the quality of life of Indonesian society that is not only limited to the welfare aspect but also can provide happiness.

In the Law of the Republic of Indonesia number 10 of 2009 on tourism, it is stated that tourism serves to meet the physical, spiritual, and intellectual needs of every tourist with recreation and travel and increase the state's income to realize people's welfare. Indonesian tourism is also expected to enhance the sense of nationalism and friendship among nations. In more detail, the objectives of Indonesian tourism in accordance with the Law on Tourism are: increasing economic growth, improving people's welfare, eradicating poverty, 
overcoming unemployment, conserving nature, environment and resources, promoting culture, lifting the image of the nation, strengthen the identity and unity of the nation, and strengthen friendship among nations. Taking into account the purpose of tourism, it seems that so much hope for the success of the tourism sector so that tourism development planning should be done comprehensively and integrated.

On the other hand, tourism activities have very high dynamics, always evolving and changing in line with the passage of time and the development of the era. This dynamic phenomenon provides uncertainty in the management of tourism activities in a region. Therefore, it needs an understanding and also holistic planning in realizing a region as a tourism destination. Through holistic understanding and planning is expected to minimize the occurrence of a failure in the planning and management of a tourism destination. The success of planning a tourism destination will be able to support the creation of quality tourism destinations so it popular in the eyes of tourists. Supported by the management of a good tourism destination will accelerate the achievement of development goals of community welfare.

Many tourism destinations develop naturally without going through comprehensive planning, leading to the potential for environmental, social and cultural issues, including conflicts of interest between communities, both with investors and the government. To minimize the negative impacts arising from the development of tourism destinations, systematic development planning is required, integrated with as much as possible to absorb the aspirations of the people, government and private sector engaged in tourism and tourism support.

Development of tourism destinations not only at the level of the conceptual but also need to be considered the implementation of the plan development of the destination is real. In this case, planning is not an individual activity, trial and error, or simply making plans to dream about the future, but also how to realize the dream; planning the development of strategic areas of tourism should include commitment and power. To implement it needs strategies, programs and action plans, and analyze each stage of achievement. The strategic plan for the development of strategic areas of tourism in situations of high uncertainty for a complex problem requires a planning method that takes into account real-life situations known as adaptive planning, a planning model based on sustainable planning principles with several options that can be implemented simultaneously, as well as adjustments/ changes in accordance with the results of monitoring and evaluation. Through adaptive planning, the development of tourism in a destination can be in line with a dynamic of tourism activities.

\subsection{National tourism development policy}

Based on the Government Regulation of the Republic of Indonesia Number 50 the Year 2011 on the National Tourism Development Master Plan (RIPParNas) 2010-2025 has been determined 50 National Tourism Destinations (DPN), in which there are 222 National Tourism Development Zone, and 88 of them are Strategic Tourism Area National (KSPN). One of the DPNs to be developed is DPN Bali - Nusa Lembongan and its surroundings, in which $11 \mathrm{KSPN}$ (Fig. 4) are identified [1]:

1. KSPN North Bali (Singaraja) and surrounding areas (Buleleng Regency)

2. KSPN Menjangan Island - Pemuteran and surrounding areas (Buleleng Regency)

3. KSPN West Bali National Park and surrounding areas (Jembrana Regency)

4. KSPN Bedugul and surrounding areas (Tabanan Regency)

5. KSPN Sanur (Denpasar City), Kuta - Nusa Dua and surrounding areas (Badung regency)

6. KSPN Nusa Penida and surrounding areas (Kelungkung Regency)

7. KSPN Ubud and surrounding areas (Gianyar Regency) 
8. KSPN Kintamani - Lake Batur and surrounding areas (Bangli Regency)

9. KSPN Besakih - Gunung Agung and surrounding areas (Karangasem Regency)

10. KSPN Tulamben - Amed and surrounding areas (Karangasem Regency)

11. KSPN Labuhan Amuk and surrounding areas (Karangasem Regency).

\subsection{Potential of KSPN around Sanur-Kuta-Nusa Dua}

The development of the National Tourism Strategic Area (KSPN) around Sanur-Kuta-Nusa Dua covers four aspects of tourism development under Government Regulation no. (A) tourism destinations, (b) tourism industry, (c) tourism marketing, and (d) tourism institutions.

The development plan of KSPN Kuta-Sanur-Nusa Dua and Surrounding covers four aspects of tourism that are described in more detail in several dimensions for each aspect of tourism, as follows. 1) Tourism destination, which includes dimensions: tourist attraction; accessibility of tourism; public infrastructure, public facilities; tourism facilities; tourism society; and tourism investment. 2) The tourism industry, which includes: tourism enterprises, tourism products, employment in the tourism industry, and tourism business partnerships. 3) Tourism marketing, which includes dimensions: market; destination image; tourism marketing partnerships and promotions. 4) Tourism Institutions, which include: laws and regulations; tourism organizations, tourism human resources, tourism research and development; and tourism partnerships.

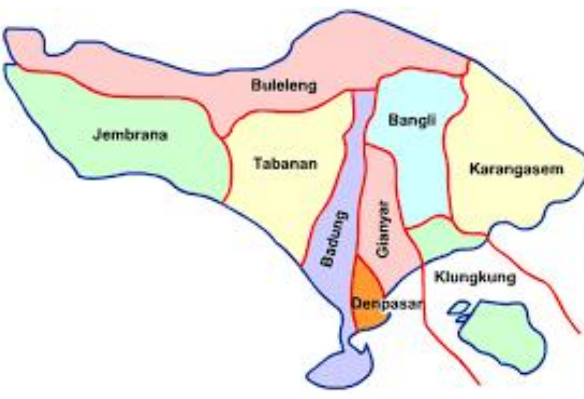

(a)

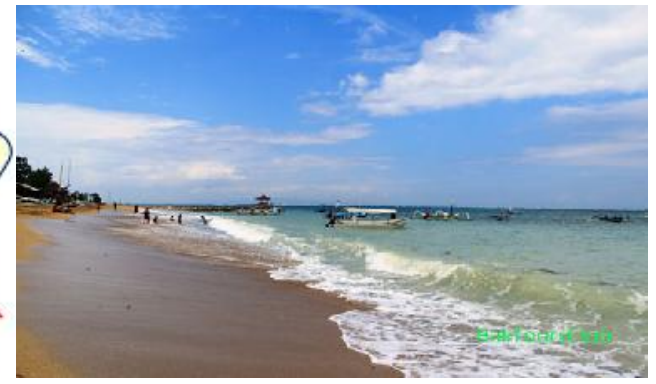

(b)

Fig. 5. (a) Map of Bali and (b) attraction of DPN area around Sanur-Kuta-Nusa Dua [21].

\subsection{Potential of KSPN in Buleleng regency}

The following section will discuss the National Tourism Strategic Area (KSPN) in Buleleng Regency. Based on the Law of the Republic of Indonesia Number 10 the Year 2009 on Tourism referred to as "Tourism Destination is a geographical area within one or more administrative areas in which there are tourist attractions, public facilities, tourism facilities, accessibility, and inter-related communities and complete the realization of tourism." Based on the above understanding, the elements of the formation of tourism destinations include tourist attraction, accessibility, infrastructure and public facilities, tourism facilities.

\subsection{Attraction potential of DPN in Bululeng regency}

Based on the Decree of the Minister of Forestry No.493/Kpts-II/1995 dated 15 September 1995, West Bali National Park has been designated with the area of 19,002.89 Ha 
consisting of 15,587.89 $\mathrm{Ha}$ in the form of land area and 3,415 Ha in the form of waters which are administratively located in Jembrana and Kab. Buleleng.

West Bali National Park is managed by a zonation system, which is by SK Director General PHKA No.SK.143/IV-KK/2010 dated 20 September 2010 on West Bali National Park Zonation, that TN. West Bali is divided into several zones including Core Zone of $\pm 8,023.22 \mathrm{Ha}$, Rimba Zone $\pm 6,174,756 \mathrm{Ha}$, Marine Protection Zone $\pm 221,741 \mathrm{Ha}$, Utilization Zone $\pm 4,294.43 \mathrm{Ha}$, Culture Zone, Religion and History covering $\pm 50,570 \mathrm{Ha}$, Special Zone $\pm 3.967 \mathrm{Ha}$ and Traditional Zone covering $\pm 310,943 \mathrm{Ha}$. West Bali National Park can be utilized for science, research, cultivation support, tourism and recreation.

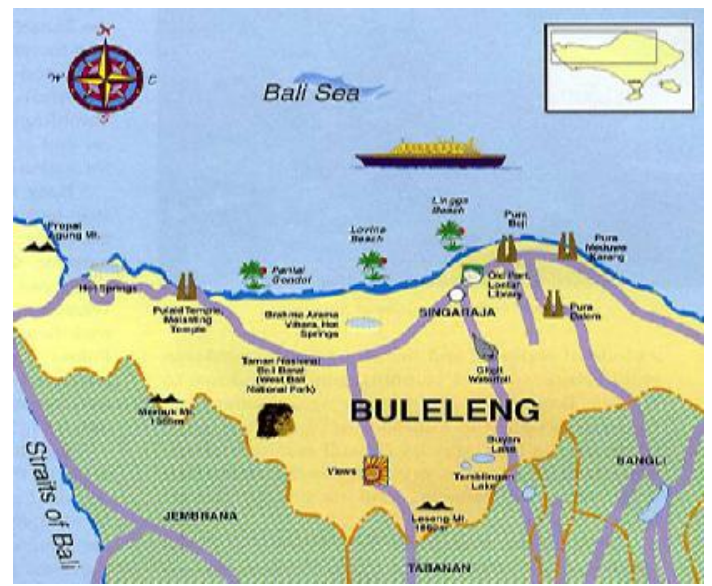

Fig. 6. DPN of Buleleng regency [22].

\subsection{Potentials of the KSPN in Karangasem regency}

Administratively, the physical condition of KSPN around Tulamben-Amed is located in Kubu and Abang sub-districts in Karangasem regency of Bali province or about $100 \mathrm{~km}$ from Ngurah Rai International Airport with the distance of about 3 (three) hour journey by road with road condition smoothly. Location KSPN Tulamben-Amed is located on the easternmost part of Bali Island which has the following area boundaries 1) North: Indian Ocean, 2) West: District Selat and Rendang, 3) East: Lombok Strait, 4) South: District of Bebandem and Karangasem.
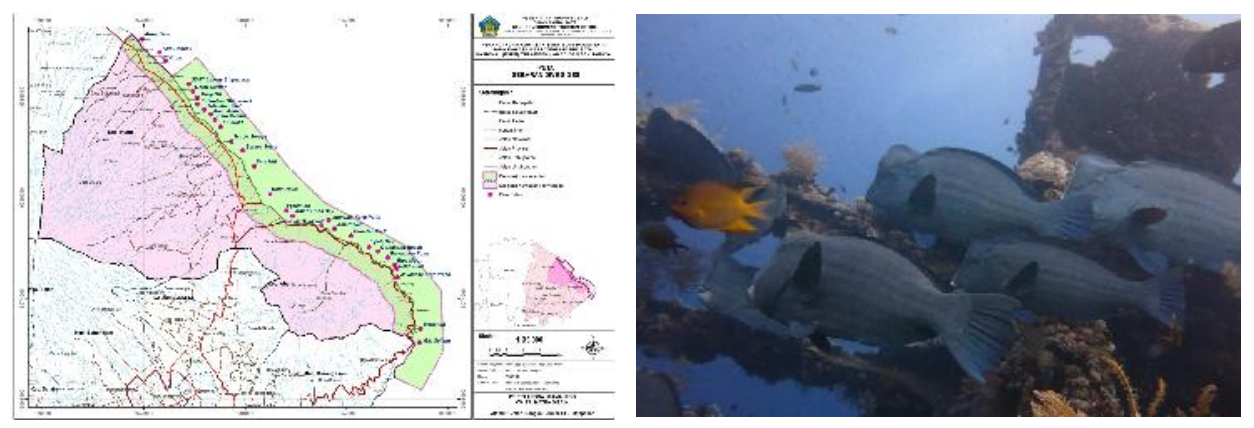

(a)

(b)

Fig. 7. (a) KSPN, (b) attraction at Tulamben-Amed in Karangasem regency [23]. 
The name of Tulamben Village comes from the word batulambih which means "many stones." This is because of the impact of the eruption of Mount Agung that affect this village from time to time. Then the name of this village turned into Batulamben and eventually turned into Tulamben Village. Tulamben village has an area of $29.16 \mathrm{~km}^{2}$.

As for the Amed region was formerly famous for its traditionally made sea salt products, but now Amed is known for its underwater beauty, so it becomes a marine tourism destination on the island of Bali. Amed has existed since the time of the Kingdom of Karangasem, where Amed was included in the territory of the Homemade Rits. Community life around Amed, in general, is fishermen. The rustic atmosphere is thick, and traditional has not been influenced by foreign culture, the beauty of the sunrise in the morning on the beach Amed is a beautiful and exotic panorama. Administratively, Amed Area belongs to Purwakerti Village, Abang District, Karangasem Regency, Bali Province.

Tulamben-Amed tourism area includes nine (9) villages, namely Baturinggit Village, Kubu, Dukuh, Tulamben, Culik, Datah, Labasari, Purwakerti and Bunutan. While Tourism Attraction located in Tulamben-Amed tourism area is Jemeluk and Tulamben Beach.

\section{Conclusions}

A follow-up study before resulted in a cognitive-mapping of three potential areas from the available 11 National Tourist Destination (DPN), they are Sanur-Kuta-Nusadua, Bali Utara, and Tulamben-Amed, in the form of Natural Resources (SDA) and Resources of Cultivation (SBD). The scientific mapping the potential areas of information database as a reference document is very useful for the preparation of the tourism strategic area development in Bali. It can be categorized as follows. 1) Tourism Destination: tourist attraction, tourism accessibility, public infrastructure, public facilities, tourism facilities, tourism community, and tourism investment. 2) Tourism Industry: tourism business, tourism product, employment in tourism industry, tourism business partnership, technological development and creativity of tourism industry. 3) Tourism Marketing: the market, the image of the destination, the tourism marketing partnership, improving the efficiency and effectiveness of tourism promotion, and the adaptation of electronic technology in the field of tourism. 4) Tourism Institutions: legislation, tourism organizations, tourism human resources, research \& development ( R \& D), and partnerships of tourism institutions.

\section{References}

1. PP Republik Indonesia 50. Rencana Induk Pengembangan Pariwisata Nasional (RIPParNas: 2010-2025) (2011)

2. N.M. Jaya, D.K. Sudarsana, N.M.A. Wiryasa, J. of Civil Eng., Architecture and Built Env. 1, 1 (2017)

3. M. Saunders, P. Lewis, A. Thornhill, 2009. Research methods for business students (Pearson, Essex, 2009)

4. Anonim. Pengembangan koridor ekonomi Indonesia, Available at: http://www.investmedan.com/libs/uploads/2016/07/PENGEMBANGAN-KORIDOREKONOMI-DI INDONESIA.jpg (2016)

5. Anonim, Geografi pariwisata Indonesia. Available at: https://image.slidesharecdn.com/geografipariwisataindonesia (2016)

6. Peraturan Pemerintah Daerah Bali 16, Rencana Tata Ruang Wilayah Provinsi Bali Tahun 2009-2029 (2009) 
7. PP Republik Indonesia 45. Rencana Tata Ruang Kawasan Perkotaan Denpasar, Badung, Gianyar, dan Tabanan (2011)

8. PP Republik Indonesia 51. Perubahan atas Peraturan Presiden Nomor 45 Tahun 2011 (2014)

9. C. Fohlin, Economic, political, and legal factors in financial system development: international patterns in historical perspective. Available at: https://ideas.repec.org/p/clt/sswopa/1089.html (2016)

10. T. Ginsburg, Law \& Society Review 34, 3 (2000)

11. Hitachi, Faktor-faktor yang mempengaruhi pembangunan ekonomi. Available at: http://seputarpendidikan003.blogspot.co.id/2016/02/faktor-faktor-yangmempengaruhi_11.html (2016)

12. A. Morh. Factors affecting economic development and growth. Available at: http://smallbusiness.chron.com/factors-affecting-economic-development-growth1517.html (2016)

13. J. Williams, 2016. Factors that affect economic development. Available at: http://smallbusiness.chron.com/factors-affect-economic-development-3940.html (2016)

14. N.M. Jaya, N.M.A. Wiryasa, Prosiding Seminar Nasional Sains dan Teknologi 2015 (2015)

15. M. Easterby-Smith, M. Crossan, D. Nicolini. 2002. J. of Man. Studies 37 (2002)

16. C. Eden, J. of Man. Studies 29 (1992)

17. C. Eden, F. Ackermann, European J. of Operation Res. 152 (2004)

18. R.K. Yin, Case study research design and methods (Sage, London, 2009)

19. R. Fellows, A. Liu, Research methods for construction (Blackwell, Oxford, 2008)

20. K. Krippendorff, Content analysis: An introduction to its methodology (Sage, London, 2004)

21. Anonim. Destinasi wisata di Sanur. Available at: https://www.google.com/search?tbm $=$ isch\&q=destinasi+wisata+di+sanur (2018)

22. Anonim. Available at: https://www.google.com/search?tbm=isch\&q=KSPN+Singaraja (2018)

23. Anonim. Available at: https://www.google.com/search?biw=QbV06LQBg\&q=DPN+ Tulamben (2018) 